\title{
Beyond Mencius and Xunzi: A Third Approach to Confucianism
}

\author{
Ren Jiantao 任劍濤 \\ Professor of Philosophy, Tsinghua University, Beijing, China \\ ren196220o1@aliyun.com
}

\begin{abstract}
After Confucius died, his disciples formed the Eight Confucian Factions [rujia ba pai 儒家八派]. The most influential among them were the moral idealist school of Mencius 孟子, which proposed the doctrine of heart-mind and human nature [xinxing 心性], and the political idealist school of Xunzi 荀子, which posited a political interpretation of Confucianism. The Mencian approach emphasized the ethics of Confucianism, whereas the Xunzian approach focused on the political application of Confucianism. Their respective weaknesses have become evident in the present. It is hoped that we can overcome their shortcomings by integrating them and formulating a new approach to modern Confucianism that uses their advantages. However, modern Confucianism had made important contributions not only in its synthesis of Mencian and Xunzian thought but, more importantly, as it carries on the approach advocated by Dong Zhongshu 董仲舒. This involves not only examining the political applications of a particular kind of scholarship on the Chunqiu gongyang zhuan 春秋公羊傳 [The Gongyang Commentary on the Spring and Autumn Annals] developed by Dong known as Gongyang scholarship [gongyang xue 公羊學] but also integrating the internal principles and politics of Confucianism. In theory, it requires an integration of the strengths of various schools to achieve a Confucian ideological system that embraces the Hundred Schools of Thought [zhuzi baijia 諸子百家]. In practice, it entails actual political application taken from a melting pot of the theoretical and political ambitions of Confucianism that is superior to the form of Confucianism that originated in the pre-Qin period [221 BCE] and other schools of thought and their successors.
\end{abstract}




\section{Keywords}

approaches to Confucianism - Dong Zhongshu - Mencius - third approach - Xunzi

Recently, there have been two propositions regarding the modern development of Confucianism. The first is the long-standing tradition of developing either the heart-mind and human nature [xinxing 心性] doctrine of the Mencian tradition or the Xunzian approach to political Confucianism [zhengzhi ruxue 政治儒學]. The second is to integrate the schools of Mencius [孟子 372-289 вСЕ] and Xunzi 荀子 [313-238 вCE] by examining Xunzi's teachings in a Mencian context. This is precisely what was advocated by Li Zehou 李 澤厚 and Liang Tao 梁濤. This second proposition is an attempt to expand Confucianism from the narrow scope of individual moral self-cultivation and find a realistic political outlet for Confucianism. In addition to these two major ideas, a genuine adherence to Dong Zhongshu's 董仲舒 [179-104 BCE] approach to open a new path for the development of modern Confucianism might be a third approach that should receive attention in the development of Confucianism.

The study of political Confucianism has long been part of contemporary Chinese academia. In 1991, Jiang Qing 蔣慶 published a programmatic article titled "From Heart-Mind and Human Nature Confucianism to Political Confucianism: On Another Direction of Contemporary New Confucianism." We can pinpoint the publication of this piece as the approximate beginning of political Confucianism.

The concept of political Confucianism has also gained momentum. However, upon analysis, it seems that most political Confucianism is actually anti-political. I do not claim that this should not be the case. Rather, I wish to emphasize that because the theoretical form of Confucianism is designated as political Confucianism, it must clearly reflect its political nature. Yet political

1 See Jiang Qing 蔣慶, “Cong xinxing ruxue zouxiang zhengzhi ruxue: lun dangdai xinruxue de ling yi fazhan luxiang 從心性儒學走向政治儒學 - 論當代新儒學的另一發展路向 [From Mind-and-Nature Confucianism to Political Confucianism: On Another Development Direction of Contemporary New Confucianism]," Shenzhen daxue xuebao (renwen shehui kexue ban) 深圳大學學報(人文社會科學版), no. 1 (1991): 80-91. 
Confucianism is not so much the result of thinking politically about politics as the result of thinking morally about politics. Why should we emphasize this point? Because political Confucianism was originally intended to make up for Mencius's supposed emphasis on the transcendental to the neglect of the political and to empiricize and politicize political Confucianism.

Li Zehou proposed "integrating Mencian and Xunzian thought" [jiantiao Meng Xun 兼祧孟荀], whereas Liang Tao suggested "unifying Mencian and Xunzian thought" [tonghe Meng Xun 統和孟荀]. ${ }^{2}$ Both approaches were intended to raise the experiential quality of Confucianism. Yet neither Li nor Liang was able to escape the fetters of anti-political Confucianism. An important reason is that Li and Liang - and Jiang Qing, who first advocated political Confucianism - looked at politics through the lens of the humanities. Showing no concern for actual political affairs, what they came up with was a fanciful version of political Confucianism. In my opinion, this kind of political Confucianism is either anti-political or alienated from politics, but it cannot be political. Based on fantasy, it can only be an expression of the value preferences of the fantasizer, which hardly resonate with actual political matters.

"Thinking about politics politically" does not mean regarding politics as a struggle of ideas or expressions of value preferences but, rather, understanding and handling political affairs through practical approaches, such as bargaining, procedural arrangements, and compromise mechanisms. That which conforms to the latter is to think about politics politically, and that which does not conform is to think about non-political and anti-political thinking. This is not to say that nonpolitical or anti-political thinking is wrong but that it has limited value in revealing political truths and little utility in constructing a political system that can actually operate.

Modern political Confucianism has opened multiple paths for inquiry. I am concerned with two of these paths. The first is the path followed by Jiang Qing, which involved separating Mencius and Xunzi - or, specifically, xinxing Confucianism and political Confucianism. Jiang emphasized the major structural difference between the two by pointing out the four extreme flaws in xinxing Confucianism. However, Jiang's recent views on political Confucianism have increasingly mellowed, and, unfortunately, he often pulls his punches.

2 See Li Zehou 李澤厚, “Ju Meng qi, xing Xun xue: wei lunlixue gangyao yi bian 舉孟旗 行荀 學 - 為《倫理學綱要》一讋 [Xunzian Doctrine under the Pretext of Mencian Thought: A Debate from The Essentials of Ethics]," Tansuo yu zhengming 探索與爭鳴, no. 4 (2017); Liang Tao 梁濤, “Tonghe Meng Xun, chuangxin ruxue 統合孟荀，創新儒學 [Innovating Confucianism by Uniting and Integrating Mencian and Xunzian Thought]," Zongjiao yu zhexue 宗教與哲學 7 (2018). 
I believe his original programmatic writings were the best way of clarifying the distinct disciplinary boundaries between the two types of Confucianism.

Let us examine those four major flaws of xinxing Confucianism, according to Jiang Qing: personalization [geren hua 個人化], metaphysicalization [xingshanghua 形上化], internalization [neizaihua 內在化], and transcendentalism [chaoyuehua 超越化]. Notably, all were described as extreme tendencies [jiduan qingxiang 極端傾向], and all were directed at neo-Confucianism developed in Hong Kong and Taiwan [Gang-Tai xin rujia 港臺新儒家]. Ming-Huei Lee 李明輝, a fourth-generation supporter of this stream of neo-Confucianism, recently wrote an article to refute Jiang Qing's view; ${ }^{3}$ however, the article only highlighted the different purposes between neo-Confucianism as it developed on the Chinese mainland and in Hong Kong and Taiwan.

By pointing out the four major flaws in xinxing neo-Confucianism, Jiang Qing delineated between the thought of Mencius and Xunzi - that is, more broadly, between xinxing Confucianism and political Confucianism - to address issues related to the development of political Confucianism. In this way, he blazed the trail for "mainland neo-Confucianism" [Dalu xin ruxue 大陸 新儒學] from xinxing Confucianism to political Confucianism. In his persuasive conclusion, Jiang argued that only by moving from xinxing Confucianism to political Confucianism can neo-Confucianism in the present solve the political problems faced in contemporary China and achieve modernization. ${ }^{4}$ Moreover, it is the only way for contemporary neo-Confucianism to develop a new “outer kingliness" [waiwang 外王].

\section{Mencian and Xunzian Thought as Both Contrasting and Complementary}

The perspectives offered by Li Zehou and Liang Tao differ from that of Jiang Qing. According to Li and Liang, the internal structure of Confucianism contrasts with and, at the same time, is complemented by Legalism. Many Confucians have integrated the doctrines of Confucianism and Legalism. In fact, Xunzi opened the door to this possibility. Although Mencius developed the moral idealism of Confucianism and its relationship to political legitimization,

3 Lee Ming-Huei 李明輝, “Gang-Tai xin rujia: tamen guanhuai xianshi, er bu zhishi 'xinxing ruxue’ 港臺新儒家: 他們關懷現實, 而不只是“心性儒學 [Hong Kong and Taiwanese Neo-Confucians Are Concerned about Reality, Not Just 'xinxing Confucianism']," Xin jing bao 新京報, September 22, 2018.

4 Jiang Qing, “Cong xinxing ruxue zouxiang zhengzhi ruxue.” 
Xunzi substantiated the political framework of Confucianism. Thus, he can be regarded as a pragmatic Confucian, who happened to engage in political affairs. Furthermore, Li talked about examining Xunzi's teachings in a Mencian context, whereas Liang advocated the unification and integration of Mencian and Xunzian thought. Both seem to be intended to reconcile contradictions in the legacy of classical Confucianism and offer viable approaches for the construction of modern Confucianism.

However, both approaches present some difficult theoretical and practical problems. Regarding Jiang Qing's approach, at least two exclusive assumptions must be satisfied to highlight the "only path" from xinxing Confucianism to political Confucianism. The first assumption is that other Confucian approaches are completely hopeless: that Jiang's approach to political Confucianism has to be taken because it is the only beacon lighting the way. The second assumption is that Jiang simply highlighted the political character of Confucianism. By comparison, xinxing Confucianism does not seem so Confucian. The former obviously disagrees with other modern neo-Confucian scholars; the latter requires Jiang's political Confucianism to accept political tests. However, because Jiang's political Confucianism is severely alienated from reality, it is a kind of political thought that upends reality and returns to tradition. Obviously, this excludes other factions that must enter the field of Confucian political design from the perspective of political consultation. Thus, it is evidently a nonpolitical or anti-political mode of thinking. Because this is a political proposition that is not adequately political, it can only be an idealized expression of a personal political stance. Because this expression is not political, the designation as "political" Confucianism is liable to raise suspicion.

The attempts by Li and Liang to unite and integrate the teachings of Mencius and Xunzi are similarly problematic. Their aim was to boil idealism and realism in one pot, forgetting that either one might not cook all the way through. Any configuration of Mencius and Xunzi could split the political considerations in two, which would not represent the true intentions of Mencius or Xunzi. In fact, it could be an attempt to connect the voices of Li and Liang to the argument for a third party.

Jiang utterly opposed the two positions within Confucianism and used them as a precondition for his definition of political Confucianism. There is, indeed, room here for correction. People can promise that a person's physical, physiological, social, and moral nature can always be clearly distinguished analytically, but they are human characteristics that can be closely connected in practice. In this regard, it can be said that uniting and integrating the thought of Mencius and Xunzi is not a practical problem but a theoretical one. From a 
practical perspective, the difference between Mencian and Xunzian doctrine is not as significant as people imagine. In this sense, Xunzi is ideally manifested in political affairs, whereas Mencius is ideally manifested in morality. In fact, throughout its long history, realism and empiricism have never been introduced into Confucianism. Liang defended the integration of the thoughts of Mencius and Xunzi for a long time, with the aim of inserting a reality orientation into Confucianism. However, Liang did not truly open the door to empiricism. If Mencius and Xunzi are so easy to integrate, how can we explain the divisive claims that Confucians have made over the past few thousand years? Could it be that they lack intelligence? Are they unaware that Mencian and Xunzian thought are ideologically consistent? Or could it be that we cannot extricate ourselves from one side of the debate?

Liang merely jumps to the other extreme in Jiang's argument. By separating the respective propositions of Mencius and Xunzi, we see the analytical differences in traditional Confucianism, and by integrating them we see the practical unity of traditional Confucianism. Yet, in their attempts to obtain a comprehensive view of Mencian and Xunzian doctrine in theory and practice, neither Jiang nor Liang is as clever as Li Zehou: his "Xunzian thought in a Mencian context” [ju Mengqi, xing Xunxue 舉孟旗, 行苗學] acknowledges the difference between the two theoretically and analytically but, in practice, connects political legitimacy to political affairs. It is commonly acknowledged that Li's approach forms part of his entire anthropological historical ontology. Therefore, his article is not a systematic theoretical explanation but merely an expression of his views. Moreover, Li only dedicates three paragraphs in his article to discussing this proposition.

The argument Li advances is straightforward and overt: that innate knowledge [liangzhi 良知] and innate ability [liangneng 良能] are inadequate for extrapolating xinxing self-cultivation as outer kingliness. This kind of extrapolation depends on the study of Xunzian doctrine. Because such a study emphasizes the evil nature of human beings, those who do good are seen as acting with deliberate effort. Manmade things are derived from this, and the situation will not resemble that which Mencius suggested, with Confucian political propositions being confined to the xinxing world.

Li's Menzian context contains an element of irony. The reason he is willing to advocate it is that the political legitimacy of Mencius's emphasis on man's innate knowledge and innate ability is deeply rooted in the fertile soil of morality and justice. Otherwise, how can such a context be supported? It is informed by Confucian moral idealism. If that were not the case, there would be no reason to support it. When you say you want to do practical things in a Mencian context, you are using it as a slogan, which not only slanders moral idealism 
but also obscures the reality of bargaining in political affairs. As for Xunzian thought, Li supports it because political affairs cannot be handled in a context of moral idealism alone - people need to be concerned about the system and measures and use them as the one and only way to solve political problems. If you advocate Xunzian thought but hide it behind moral idealism, not only will you be unable to participate in the real political world but you will also have no way of resolving matters related to political governance.

Thus, the context and the approach are two different things. Liang tried to unify the doctrines of Mencius and Xunzi but landed himself in a predicament: what he wished to accomplish and the final result could not be reconciled. This is because when the Mencian context and Xunzian thought are in opposition, the former looks at the future and the long term, whereas the latter focuses on the present and the process. As a result, the two are completely incompatible. With this in mind, how can unity be achieved?

Let us step out of the humanities for a moment and consider the matter from the perspective of social science. It is commonly acknowledged that policy decision-making is the result of the elements of contemporary game theory. 5 In other words, this is not something that can be resolved by merely choosing a particular context or approach. Li may have treated them as separate but integrated tasks; however, it seems that there is no link that connects the two. For this reason, Liang emphasized that the Confucian xinxing theory is still a necessary center and intermediary around which the question of what pretext to use can be solved. At the same time, the question of what approach to adopt provides a beacon to guide us forward. This will enable us to look up at the stars while our feet remain firmly planted on earth.

This inexplicable and unrealistic hope by the Chinese is laughable. This is not to say that Liang is laughable, only that the ideal is. It would be impossible to look up at the starry sky and discuss principles with one's feet on the ground in order to deal with concrete matters because these two approaches are antithetical. It should be understood that the establishment of ideals and moral cultivation are completely different from resource requirements, actual allocation, and decision-making about and specific implementation of policy. When gazing at the starry sky, people do not need to have any policy considerations at all - when they look upward, the most important basis for

5 See David H. Rosenbloom et al., Gonggong xingzhengxue: guanli, zhengzhi yu falü de tujing 公共行政學: 管理、政治與法律的途徑 [Public Administration: Understanding Management, Politics, and Law in the Public Sector], trans. Zhang Chengfu 張成福 et al. (Beijing: Zhongguo renmin daxue chubanshe, 2002), 335-69. Chapter 7, "Decision making," provides a description and analysis of political decision-making. Though its discussion is modern in context, it can be applied more generally. 
policy decision-making is politics, regulations, and desires; when they look downward, policy decision-making and implementation need compromise, negotiation, and satisfaction. Administrative power is the key link between decision-making and execution.

Thus administrative management has become an important issue in the modern political system. Between political ideals and reality, there is a complicated political game. This is a difficult problem that ideals cannot solve and to which policy implementation does not pay enough attention. Political matters must be resolved satisfactorily through procedures, deliberation, and compromises.

In my view, Liang is actually trying to connect Li's separation of context and approach. Is the train of thought of Liang and Li completely at odds with that of Jiang Qing? I do not believe that to be the case. Li thought it was practical for Jiang to separate Mencian and Xunzian thought and transition to Liang's proposal for unification of them. Liang believed that Li might be in danger here: how could Xunzian doctrine in the context of Mencian thought adhere to Confucian values? Is it not the case that practice alone will determine the future and destiny of Confucianism? Will the Confucian value system be lost because of this? In my opinion, this is a roadblock set up by scholars on the mainland for discussing Confucianism.

One might ask, is it sufficient for Confucians to insist on humane love [ren'ai 仁愛], or must they also insist on "inner sageliness, outer kingliness" [neisheng waiwang 內聖外王], a concept that modern Confucianism uses to define Confucians and Confucianism? Regarding it as the core of Confucianism is a failure to understand the spirit of Confucianism, a misunderstanding not of morals but of principles. This is because what Confucianism pays more attention to is not internal and external issues but fundamental ones, as indicated in the phrase "all must take self-cultivation as the foundation" 6 and the "three principles and eight items" [sangangbamu 三綱八目]. Only by viewing them as our starting point can we arrive at an accurate understanding. ${ }^{7}$

Li tried to consolidate the downward movement of Xunzian doctrine so that it would be equivalent to that of Mencius; at the same time, he used the Mencian pretext as merely that - a pretext - which allowed it to encompass the politics and pragmatism of Xunzi. In this way, he achieved the best of both

6 Zhu Xi 朱喜, Sishu zhangju jizhu 四書章句集注 [Collected Commentaries on the Four Books Arranged in Sections and Sentences] (Beijing: Zhonghua shuju, 1983), 4.

7 See Ren Jiantao 任劍濤, “Neisheng de gui neisheng, waiwang de gui waiwang: ruxue de xiandai tupo 內聖的歸內聖, 外王的歸外王: 儒學的現代突破 [Internal Sageliness and Outer Kingliness: A modern Breakthrough in Confucianism]," Zhongguo renmin daxue xuebao 中國人民大學學報, no. 1 (2018). 
worlds, with each doctrine in its proper place. Yet it begs the question: If you use the pretext for different approaches, will Confucianism be split between value proposition and political practice? Liang's integration of Mencian and Xunzian doctrine was, in fact, an attempt to make up for Li's missteps.

How the traditional resources of Confucianism and the modern orientation of Confucianism should be effectively dealt with remains a quandary. Moreover, within Confucianism, whether the directions of Li, Liang or Jiang should be followed has become a difficult problem. The political character of political Confucianism is significantly different from the original path of Confucianism and Confucius himself. This needs to be corrected. I believe that, based on Liang's ideas, the integration of Mencius and Xunzi requires us to observe the extent to which Confucian thought has penetrated that of Xunzi and presents us with two kinds of idealism: moral idealism and political idealism.

The problem is often that people do not regard Xunzi's political ideas as idealism. It is assumed that, as long as Xunzian political thought is mentioned in terms of its realistic and empirical orientation, Xunzi can be seen as a designer of Confucian plans for handling political affairs. However, this is a misunderstanding of Xunzi. If people are willing to distinguish between ideal politics and political ideals, then there will be a pair of concepts that distinguish Mencian and Xunzian thought: Mencius talks about ideal politics, and humane governance [renzheng 仁政] is the simplest description of ideal politics. Although it comes from liangzhi and liangneng - and not from the foundation of geometrical knowledge in Plato's [427-347 BCE] Republic - it rejects the constraints of reality and has a powerful normative force that transcends time and space. As a result, his plan might not stand up to empirical testing. A successful or failed political experience can neither verify nor subvert the moral idealism of Mencius, as it always remains the most important political target. Like communism, moral idealism is something that mankind can only work toward but never achieve completely. If you force the implementation of ideal politics, you will only fall into the quagmire of moral despotism. When people turn idealism into a realistic plan, they turn ideals into reality, and ideals and reality will both be buried.

The political idealism expressed by Xunzi can be misleading. The misinformed assumption is often made that concrete political plans can exist only under ideal politics. Many believe that the politics proposed by Xunzi - of "the character of a king" [wangzhe zhi ren 王者之人], "the system of a king" 
[wangzhe zhizhi王者之制], “the law of a king” [wangzhe zhifa 王者之法], “the words of a king” 王者之言 [wangzhe zhiyan], and so on - is the implementation of Way-of-kings [wangdao 王道] politics. This is a major misunderstanding. Naturally, the most idealistic plan of wangdao politics must be found in the Mengzi. However, what Xunzi provided was only a sub-ideal plan for wangdao politics, not an implementation plan.

If we look at political issues from an idealistic perspective, ideal politics is the primary target, and political ideals are secondary targets. The latter is politically oriented, but it does not deal specifically with political affairs. The political treatment and handling of political affairs were actually performed by Xunzi's students, though they moved in the direction of Legalism. The reason that Confucianism combines with Legalism to form a political ideology characterized by Confucian-coated Legalism [rubiao fali 儒表法裡] is a problem encapsulated in the phrase "all doctrines serve the ruler" [wu wei zhi zhe 務為治者].

Only by entering the political world can we truly begin to deal with actual political problems. The Qin dynasty [221-207 BCE] attempted to build an empire but met its demise after two generations, which proved that the Legalists did not adequately deal with political issues. The policies adopted during the Han dynasty [202 ВСЕ-220] by Dong Zhongshu and Emperor Wu 武 [r. 141-87 BCE] linked ideal politics, political ideals, and political affairs. It was an approach aimed at integrating various schools and infiltrating the political world, rather than the result of confrontation or penetration of Mencian and Xunzian tendencies. This represents the third path of Confucianism out of the naive idealist political world and into the real political world - an approach to political thought beyond Mencius and Xunzi.

We can be guided by Jiang's approach to Gongyang scholarship [gongyang xue 公羊學] as a kind of Confucianism with political legitimacy criteria reintroduced. Jiang pointed out that gongyang scholarship was first initiated by Confucius and later carried forward by Mencius and Xunzi; Sima Qian 司馬遷 [145-90 BCE] played a historic role, and Dong Zhongshu and He Xiu 何休 [129$182 \mathrm{BCE}]$ together perfected it. Theories formulated in gongyang scholarship on establishing social order - such as new king [xinwang 新王], Lu as the ruling dynasty [wanglu王鲁], Confucius as the king [Kongziweiwang 孔子為王], and Confucius as reformer [Kongzi gaizhi 孔子改制] - had a significant impact on later Confucians. The political theories it proposed - such as those on the Son of Heaven at the top rung [tianziyijue 天子一爵], resonance between Heaven and man [tianren ganying 天人感應], debates on the Yi and the Xia [Yi Xia zhi bian 夷夏之辨], and the standard and the expedient [jingquan 經權] - played a leading role in Confucian political thinking. 
As for historical philosophy, theories on three worlds [sanshi 三世], grand unity [dayitong 大一統], and bridging three traditions [tongsantong 通三統] profoundly shaped the historical and political ideas of Confucianism. ${ }^{8}$ However, because Jiang discussed Dong in the context of the development of gongyang scholarship, it is necessary to further emphasize the prominent position of the Dong family in the maturation of Confucianism. Additionally, we need to better understand Dong's breakthrough in blazing the trail for politically oriented Confucianism.

Dong wanted to absorb qualities from numerous schools of thought while keeping Confucianism at the core and develop a theory of Confucianism focused on handling political affairs. In this way, he targeted the shortcomings of Confucianism so as to open up a new way for the doctrine to penetrate political practice through the development of a theoretical framework. Jiang's development of Dong's gongyang scholarship is a Confucian political ideological approach worthy of recognition. However, Jiang emphasized the tradition of gongyang scholarship theory rather than its practical application, which meant that he could not clarify the key conditions for the implementation of Dong's plans.

The theoretical framework conceived by Dong was based on the ancient political system. He devised the concept of restricting imperial power, embodied in the propositions of correspondence between Heaven and man [tianren xiangfu 天人相副], resonance between Heaven and man [tianren ganying 天人感應], and reprimands from Heaven and man [tianren qiangao 天人譴告]. Although they do not propose a genuine decentralization of power on a horizontal level with mutual restrictions - they are only a product of quasitheocratic thinking supported by psychological intimidation in the form of divine condemnation - the separation of nature and humanity in the first type of Confucianism is an obvious correction. Dong's approach gave Confucians a new way to allow Heaven to inhibit the power of the imperial government. As such, it represented a breakthrough in the history of Confucian political thought. [As Dong writes in] the following passage:

Man can give birth but cannot create man. It is Heaven that makes man. The reason man becomes man is his accordance with Heaven. Heaven is the ancestor of man. This is why human beings are similar to Heaven.... A ruler does not know the heavenly aspects he possesses but governs his

8 See Jiang Qing, “Gongyangxue de jiben sixiang 公羊學的基本思想 [Basic Concepts in Gongyang Scholarship]," in Gongyangxue yinlun 公羊學引論 [An Introduction to Gongyang Scholarship], ed. Jiang Qing (Shenyang: Liaoning jiaoyu chubanshe, 1995). 
state in accordance with Heaven. If his style of governance corresponds to the four seasons born in nature, he will be able to treat the innate nature he inherited from the heavens faithfully. The benevolent rule of Yao 堯 and Shun 舜 cannot be superior. The people can be made to live or die, but they must be prevented from causing chaos. Thus, refrain from enacting that which is not in conformity with the proper course, and do not say that which is not in line with the laws. This is what I mean. ${ }^{9}$

This is the first major amendment to the pre-Qin [221 BCE] Confucian concepts of doing one's utmost [qiangmianerwei 強勉而為], sacrificing one's life to achieve virtue [shashenchengren 殺身成仁], and sacrificing one's life for justice [sheshengquyi 舍生取義], which espouse a subjective kind of fighting spirit. Between the high order of Heaven and the order of political position, the former carries significance for the latter in terms of making laws and formulating regulations. This is a three-dimensional conceptual framework of Heaven and man constructed for Confucianism, rather than a planar moral structure in which human beings think of themselves. Jiang paid particular attention to this point and gave a due explanation.

Dong's breakthrough role in the rise of Confucianism during the Han dynasty was also manifested in his integration of Confucian theory with Confucian political applications, a task unachieved by previous schools of Confucianism. Confucius developed a spiritual approach aimed at restoring the politics in which the Way prevails under Heaven [tian xia you dao 天下有道], but his own political practice was obviously unsuccessful. Later Confucians could only look at Confucius as the uncrowned king [suwang 素王], which can be said to highlight the embarrassment of Confucius' political practice most accurately and the asymmetry between the profound influence of political thought and the influence of political practice. Mencius, like Confucius, traveled through the various domains in a state of panic as he was only able to give lectures and pass his knowledge on to his students.

Sima Qian's appraisal of Mencius - "his thinking is grand but impractical and of no use in terms of making things better"10 - suggests that Mencius clearly deviated from Confucius' line and embarked on the road of lofty moral idealism. Xunzi greatly influenced the intellectual climate in the late Warring

9 Dong Zhongshu 董仲舒, Dong Zhongshu ji 董仲舒集 [Works of Dong Zhongshu], ed. Yuan Changjiang 袁長江 et al. (Beijing: Xueyuan chubanshe, 2003), 242.

10 Sima Qian 司馬遷, “Mengzi Xun qing liezhuan 孟子荀卿列傳 [Memoirs of Mencius and Excellency Xun]," in Shiji 史記 [Records of the Grand Historian] (Beijing: Zhonghua shuju, 2010), 4964. 
States period [475-221 BCE]. However, as the county magistrate [xianling 縣令] of Lanling 蘭陵, Xunzi had no opportunity to put his "rule of the king" theory [wang zhe zhi zhi 王者之治] into practice. Meanwhile, Dong introduced into Confucianism doctrines from various schools, especially the concept of the boundary between Heaven and man [tian ren zhi ji 天人之際] from the yin-yang school [yinyangjia 陰陽家]. He created a philosophical system that carried on the original meaning of Confucianism but also a new and clearer theoretical basis. At the same time, by means of the Three Disquisitions on the Correlations of Heaven and Man [tian ren san ce 天人三策], Confucian ideas now had political applications in the Han dynasty, which directly shaped Han political and had profound effects on the development of the premodern Chinese political system. Confucianism guided the construction of the theoretical system and the design of the practical plan and achieved overall and real success. It began with Dong. The slogan "expound only on Confucius and prohibit the Hundred Schools of Thought"ll is a manifestation of the new theoretical system, and the "modified" politics demonstrate the practical plan.

Dong enabled Confucianism to stand at the pinnacle between theory and practice. By integrating the strengths of all the schools, Dong allowed Confucianism to stand on the spiritual basis contained in the phrase "the resonance between Heaven and man is fearsome."12 He also developed a broad ideological system aimed at describing humanity's interdependent relationship with the divine. This achievement was completely beyond the reach of the other successors of pre-Qin scholars.

Dong also successfully introduced the concept of Confucianism into the political process and realized the expected goal of Confucianism to reverse the situation in which there is no Way under Heaven [tian xia wu dao 天下無道] and restore the order in which the Way prevails under Heaven [tian xia you dao 天下有道]. In this way, the development of Confucianism was internally integrated with Confucian political practice. This meant Confucianism could remain the realpolitik of the Han dynasty for centuries and profoundly, extensively, and durably affect the political life of Chinese society for generations to come. Thus, an understanding of Confucianism as the ideological mainstream of premodern Chinese politics is not possible without examining Dong's contributions.

11 Dong Zhongshu, “Hanshu: Dong Zhongshu zhuan 漢書· 董仲舒傳 [Biography of Dong Zhongshu in the History of the Han Dynasty]," in Dong Zhongshu ji, 442.

12 Dong Zhongshu, "Tian ren san ce 天人三策 [Three Disquisitions on the Correlations of Heaven and Man]," in Dong Zhongshuji, 6. 
The significance of Dong's approach to Confucianism is his synthesis of the various schools of thought and the integration of that synthesis with Confucianism. He also reintroduced the view of Confucian secular rationality to an understanding of people's relationship with Heaven. This was a major theoretical achievement that indicated a new direction for Confucianism. At the same time, Dong integrated theory with political practice. He presented his theory to Emperor Wu as a governance strategy [duice 對策] in order to demonstrate that his scholarship had a political application and was not just rigid adherence to old ideas. It affected the basic policies of imperial power in ancient China and completely changed the fate of Confucianism from bordering on being outdated and irrelevant to becoming the mainstream theory that defended political legitimacy.

Yet on the topic of theocratic power restricting imperial power, the concept of a state religion did not seem to cross Dong's mind. Once the bold and reckless mentality of the emperor could no longer be restrained by intimidation, Dong was powerless to implement measures that could restrict imperial power, let alone decentralize it. But this is not something to be ashamed of. No other polities in antiquity achieved such a breakthrough, though a special exception can be made for the Romans. We also have no reason to demand that the ancients should have achieved it. At present, this is a responsibility that we ourselves need to bear. If people today are trying to uphold Confucianism, then Dong's third Confucian line is an approach based on true political reality. Perhaps political Confucianism could come to life by pushing forward with Jiang's gongyang scholarship and realizing the basic conditions for the restriction of imperial power that Dong failed to enact. We might even be able to guide Chinese politics onto a path that would restrain power and protect rights.

\section{Translated by Carl Gene Fordham 傅君愷}

\section{Works Cited}

Dong Zhongshu 董仲舒. Dong Zhongshuji 董仲舒集 [Works of Dong Zhongshu]. Edited by Yuan Changjiang 袁長江 et al. Beijing: Xueyuan chubanshe, 2003.

Jiang Qing 蔣慶. “Cong xinxing ruxue zouxiang zhengzhi ruxue: lun dangdai xinruxue de ling yi fazhan luxiang 從心性儒學走向政治儒學 - 論當代新儒學的另一發展 路向 [From Mind-and-Nature Confucianism to Political Confucianism: On Another Development Direction of Contemporary New Confucianism]." Shenzhen daxue xuebao (renwen shehui kexue ban) 深圳大學學報(人文社會科學版), no. 1 (1991): 8o-106. 
Jiang Qing 蔣慶. Gongyangxue yinlun 公羊學引論 [An Introduction to Gongyang Scholarship]. Shenyang: Liaoning jiaoyu chubanshe, 1995.

Lee Ming-Huei 李明輝. “Gang-Tai xin rujia: tamen guanhuai xianshi, er bu zhishi 'xinxing ruxue’ 港臺新儒家: 他們關懷現實, 而不只是“心性儒學” [Hongkongese and Taiwanese Neo-Confucians Are Concerned about Reality, Not Just 'xinxing Confucianism']." Xin jing bao 新京報, September 22, 2018, Bo6.

Li Zehou 李澤厚. “Ju Meng qi xing Xun xue: wei lunlixue gangyao yi bian 舉孟旗行 荀學 - 為《倫理學綱要》一辡 [Xunzi Doctrine under the Pretext of Mencian Thought: A Debate from The Essentials of Ethics].” Tansuo yu zhengming 探索與爭 鳴, no. 4 (2017): 58-62.

Liang Tao 梁濤. “Tonghe Meng-Xun, chuangxin ruxue 統合孟荀, 創新儒學 [Innovating Confucianism by Uniting and Integrating Mencian and Xunzian Thought].” Zongjiao yu zhexue 宗教與哲學 7 (2018): 75-84.

Ren Jiantao 任劍濤. “Neisheng de gui neisheng, waiwang de gui waiwang: ruxue de xiandai tupo 內聖的歸內聖, 外王的歸外王:儒學的現代突破 [Internal Sageliness and Outer Kingliness: Modern Breakthroughs in Confucianism]." Zhongguo renmin daxue xuebao 中國人民大學學報, no. 1 (2018): 82-94.

Rosenbloom, David H., et al. Gonggong xingzhengxue: guanli, zhengzhi yu falü de tujing 公共行政學:管理、政治與法律的途徑 [Public Administration: Understanding Management, Politics, and Law in the Public Sector]. Translated by Zhang Chengfu 張成福 et al. Beijing: Zhongguo renmin daxue chubanshe, 2002.

Sima Qian 司馬遷. Shiji 史記 [Records of the Grand Historian]. Beijing: Zhonghua shuju, 2010.

Zhu Xi 朱喜. Sishu zhangju jizhu 四書章句集注 [Collected Commentaries on the Four Books Arranged in Sections and Sentences]. Beijing: Zhonghua shuju, 1983. 